\title{
The Profitability of Paddy Cultivation and Farmers' Perception in West Bengal with Special Reference to Purba Bardhaman District
}

\author{
Barun Kumar Paul ${ }^{\dagger}$
}

\section{Abstract}

Many economists and experts opined that agriculture is an unprofitable activity in India nowadays, mainly because of increasing cost and low prices of farm produce. However, during the field survey in Galsi-I and Galsi-II Blocks of Purba Bardhaman, it was observed that many farmers do not think so. In this context, using the secondary data on the cost of paddy cultivation for the period 199697 to 2015-16, this paper analyses the cost and returns from paddy cultivation in West Bengal. It is observed that the cost has increased at a very high rate. Paid out cost at current prices during the last decade has increased by 12.1 per cent per annum. However, they do not realise the right price of their produce, and consequently, the profit margin has declined. Data reveal that farmers incurred losses in paddy cultivation upto 14 times except for in 2007-08 and in 2009-10 during 2000-01 to 2015-16. They are also being deprived of getting even the minimum support prices (MSP) due to loopholes in government initiatives. Using primary data, this paper explains why many farmers think that paddy cultivation is still a profitable activity. In doing so, the research finds that they miscalculate the cost of cultivation and that is why they perceive the profit margin to be higher. The kinds of cost that they do not calculate include family labour, depreciation charge, interest on capital, the rental value of owned land, and others. Another cause for exaggerated profit is that farmers include income from paddy business as return from agriculture.

Keywords: Cost of Cultivation, Average Net Return, Farmers' Perception, Compound Annual Growth Rate (CAGR), Purba Bardhaman, West Bengal, India

\footnotetext{
${ }^{\dagger}$ PhD Researcher, Department of Geography, The University of Burdwan, West Bengal

E-mail: barunkpaul.geo@gmail.com

(C) 2019 Paul. This is an Open Access article distributed under the terms of the Creative Commons Attribution License (http://creativecommons.org/licenses/by/2.0), which permits unrestricted use, distribution, and reproduction in any medium, provided the original work is properly cited.
} 


\section{Introduction}

The agrarian crisis is one of the most critical issues in India nowadays (Raghavan, 2008; Posani, 2009; Shroff, 2019). Farmers' suicide has also become a common phenomenon after the early 1990s (Narayanamoorthy, 2013, p. 104). It is not only confined in backward regions, instead farmers of most productive agricultural regions such as Karnataka, Punjab, West Bengal, Andhra Pradesh and Maharashtra are also ending their lives mainly because of their massive indebtedness (Biru \& Barpujari, n.d.). In this connection, it is opined that "indebtedness and other related problems are mainly caused by poor returns from crop cultivation; therefore, one should study the issue of profitability" (Narayanamoorthy, 2013, p. 106; Pushpa, Srivastava, \& Agarwal, 2017, p. 389).

Before the Green Revolution in India, the main problems facing the agricultural sector were insufficient crop production and lower yield rate (Rao, 2004, p. 20; Srinivasan, 2007, p.131). At that time, the primary concern of the agricultural price policy was to ensure that the gap between demand and supply of foodcrops did not result in excessive price rise and that minimum support price (MSP) of the food crops were below market price (Ray, 2007, p. 36; Tripathi, 2013, p. 91). However, meagre profitability and frequent loss in crop production is the main concern at present. Though the current price policy aims to protect the farmers' income and to provide them incentives (Tripathi, 2013), it has failed to do the needful and recently we have witnessed sporadic farmer protests in states like Punjab, Madhya Pradesh and Maharashtra, demanding loan waivers against crop loss and right price for their produce (Langa \& Sriram, 2017; "Why the farmers stormed", 2018; Mohanty, 2018). On farmer distress, Swaminathan (2016, p. 138), father of the Green Revolution in India, opined that "there is no other profession that has such low returns" and suggested that the government should set the minimum support price (MSP) at the total cost plus 50 percent return.

There are many studies (Raghavan, 2008; Dev \& Rao, 2010; Tripathi, 2013; Narayanamoorthy, Ali,
\& Suresh, 2014; Chand, Saxena, \& Rana, 2015; Srivastava, Chand, \& Singh, 2017) on costs and returns from crop cultivation. Almost all of these studies have concluded that the nominal cost of crop production has increased rapidly, while profitability of crop cultivation has decreased over time. However, these studies have mainly highlighted the national scenario. There is a lack of studies focusing on profitability of crop cultivation in the state of West Bengal. Besides, no importance has been given on farmers' perception in these studies. In light of this backdrop, this study aims to examine the profitability of paddy cultivation and farmers' perception in the district of Purba Bardhaman, West Bengal. Purba Bardhaman district has been formed on $7^{\text {th }}$ April 2017 bifurcating erstwhile Bardhaman district. Rich alluvial plain, favourable climate, irrigation facility, etc. have made Purba Bardhaman as one of the most agriculturally developed districts of West Bengal. Paddy is the major crop of this district. Undivided Bardhaman district was known as the 'rice bowl of West Bengal' for paddy production and bulk of the paddy was produced in what is now known as Purba Bardhaman district.

The study begins by outlining the objectives. This follows a description of the methods and methodological issues deployed. The results are then critically discussed in the sections following this.

\section{Objectives}

Considering the current agrarian crisis related to lower returns from cultivation and dearth of studies on this issue in West Bengal, it has been tried to assess the costs and returns from paddy cultivation in this state. The main objectives of this paper can be summarised as:

- to assess the increase in the real cost as well as the nominal cost of paddy cultivation in the last twenty years from 1996-97 to 2015-16;

- to analyse the changes in returns from paddy cultivation during that time period; 
- to understand how farmers have been benefitted from MSP of paddy, and

- to assess how farmers calculate the cost of cultivation and analyse why they think that agriculture is still a profitable livelihood activity.

\section{Data and Method}

This study is mainly based on secondary data on the cost of cultivation ( $\mathrm{CoC}) /$ cost of production (CoP) collected and published by the Directorate of Economics and Statistics, Ministry of Agriculture, Government of India. Time series data on COC and CoP for paddy in West Bengal for the period of 1996-97 to 2015-16 is used here.

Data related to costs, returns and MSP have been deflated by the consumer price index for agricultural labourers (CPIAL) of West Bengal with the base year of 2004-05 to examine how the costs, returns of paddy cultivation and MSP of paddy have changed in real terms. However, costs and returns at current prices/nominal prices ${ }^{1}$ have also been presented. For analysing CoC of paddy, the aforementioned time period (1996-97 to 2015-16) has been divided into two equal phases so that we can make a comparison. Besides, trend of MSP, ratio of MSP to cost of production, and ratio of realised price to MSP has been presented.

The primary data has also been used to study the farmers' perception as well as to present cost calculation as done by them. The primary data has been collected from a field survey conducted in the year 2016. The field survey covered 360 farmer households ${ }^{2}$ located in 18 villages from 18-gram panchayats (one village from each gram panchayat) of Galsi-I and Galsi-II C. D. Blocks of Purba Bardhaman district, West Bengal. From each village, 20 farmer households have been selected using purposive sampling method and surveyed using semi-structured questionnaire. The farmer households (FH) have

\footnotetext{
${ }^{1}$ In economics, current or nominal prices refer to the prices which have not been adjusted for inflation. ${ }^{2} \mathrm{~A}$ household in which there are at least one farmer (a person who possesses some land and performs
}

been classified into six categories - a) landless lessee $^{3}$; b) landless sharecropper; c) marginal with ownership holding of less than 1 hectare; d) small with ownership holding of 1-2 hectares; e) medium with ownership holding of 2-4 hectares; and f) big with ownership holding of more than 4 hectares to understand inter-class variation in perceptions among the farmers. In studying farmers' perception about profitability, the questions were set following a 5-point Likerttype scale. Two-way closed-ended questions (like yes/no) were also prepared on different cost items. A key informant survey was also conducted to gather information on how Assistant Directorate of Agriculture (ADA) staffs calculate costs and returns from crop cultivation.

\section{Cost Items and Cost Concepts}

Before discussing the profitability of paddy cultivation, it would be pertinent to know how many cost items there are and which types of cost concepts are used to assess profitability. There are two broad categories of cost items: i) paid out cost items, and ii) imputed cost items. Paid out cost items are those items for which farmers have to spend money or goods. These include hired labour, either human labour, animal labour or machine labour; maintenance expenses of own machine and animals; material inputs such as seed, fertilisers, manure, pesticides and irrigation; depreciation; rent paid for leased-in land; interest on working capital; and land revenue, cess and other taxes.

On the other hand, imputed cost items are those items for which no money is actually spent but they do contribute towards the growth of crop. These items include family labour, interest on fixed capital, managerial input of the farmer, and so on. Proper evaluation of such items in terms of the monetary equivalent is vital for correct assessment of the cost of production (Nath, 2008). Based on these cost items, Commission on Agricultural Costs and Prices (CACP) has developed and used nine cost concepts.

agricultural activities in any part of that land during the 365 days preceding the date of survey).

${ }^{3}$ Households having no ownership of land, but lease in land for a particular time period have been considered as landless lessee farmer households. 
However, the most used cost concepts are Cost $A 2$, Cost $C 2$ and Cost $A 2+F L$, and thus have been used in this study. $A 2$ cost is termed as paid out cost. $\mathrm{C} 2$ cost is more or less equivalent to the total cost. Cost $A 2+F L$ includes $A 2$ cost plus an imputed value of unpaid family labour.

\section{Assessment of Cost of Paddy Cultivationin West Bengal}

There are a number of studies on the profitability of Indian agriculture (Raghavan, 2008; Tripathi, 2013; Srivastava et al., 2017). From most of these studies, it has been observed that the profitability of agriculture has declined considerably during the last few years, mainly due to increasing input cost leading to the agrarian crisis in India. Conversely, Chand et al. (2015) opined that there was no squeeze in the farmers' income or profitability in farming during 1983-84 to 2011-12; instead, per cultivator farm income increased by 7.3 per cent a year.

We should turn our attention now to the cost of the paddy cultivation. Narayanamoorthy (2013) in one of his study opined that though the area under paddy cultivation and production have increased from 1950-51 to 2008-09, the paddy farmers have either faced losses or realised a very marginal profit, especially after the 1990s. In the context of paddy cultivation in West Bengal, Srivastava et al. (2017) noted that in 2014-15, the cost of paddy production in this state was the highest among the 19 major paddy producing states in India. At the same time, the output cost ratio of paddy was lower than the output cost ratio of wheat, gram, arhar (split toor or tuvar dal known as pigeon peas), rapeseed and mustard, and sugarcane.
However, the trend in the average cost of paddy cultivation in terms of current prices and real prices in West Bengal during the past 20 years is shown in Figure 1. The trend in C2 cost at base year prices represents changes in real cost. It indicates that there is a marginal change in the real cost of cultivation ( $\mathrm{CoC}$ ). During the period from 1996-97 to 2015-16, the nominal CoC of paddy has increased by 7.94 per cent per annum, whereas the real $\mathrm{CoC}$ of paddy has increased only by 1.74 per cent per annum (Table 1 ). This difference indicates that inflation of the inputs mainly has resulted in increased cost of paddy cultivation.

If we look into the changes in $\mathrm{CoC}$ in two time periods, it is observed (Table 1 ) that the recent time period has experienced a steeper rise in CoC of paddy. Compound annual growth rate (CAGR) in real C2 cost during 2006-07 to 201516 was 2.94 per cent, which is three times greater thanthe CAGR in real C2 cost for the period of 1996-97 to 2005-06. Input use has experienced 2.5 times more growth during 2006-07 to 2015-16 as compared to $1996-97$ to 2005-06.

However, the farmers are not concerned about the real cost. They are worried about the increase in nominal CoC. CAGR for A2 and C2 cost during the last period is more than double that of the previous period (see, part B of Table 1). Thus, it is evident that the cost of paddy cultivation has witnessed rapid growth during the last ten years caused by price rise as well as more input use. 


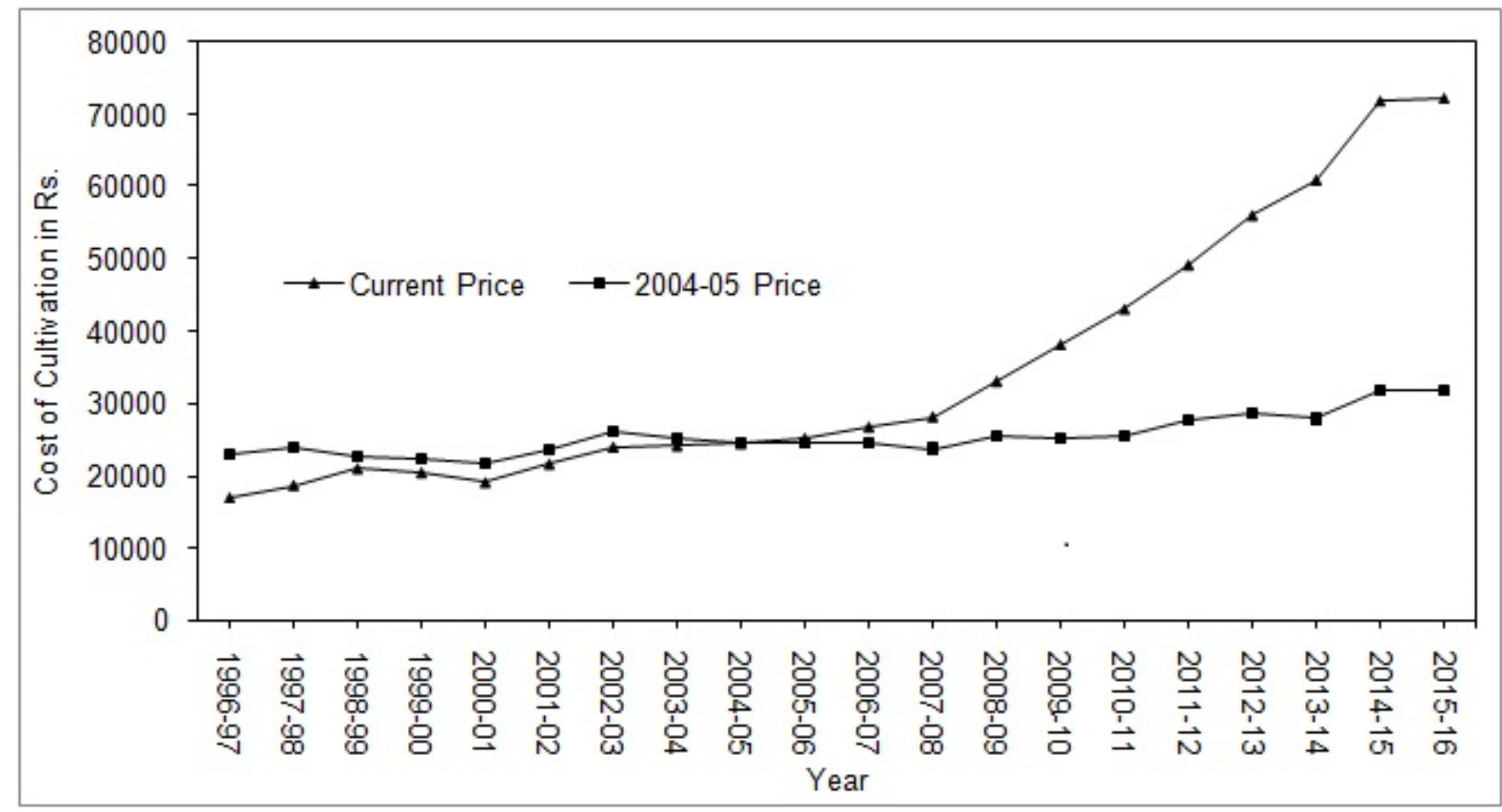

Figure 1: Trend in C2 Cost of Paddy Cultivation in West Bengal

Source: Computed from the cost of Cultivation Data of Various Years Published by the Directorate of Economics and Statistics, Ministry of Agriculture and Farmers Welfare

\begin{tabular}{|l|l|l|l|l|}
\hline Table 1: Average Cost and CAGR in Cost of Paddy in West Bengal \\
\hline $\begin{array}{l}\text { Period } \\
\text { Cost }\end{array}$ & $\begin{array}{l}\text { Average C2 } \\
\text { cost }\end{array}$ & CAGR in (\%) \\
\hline
\end{tabular}

\begin{tabular}{|c|c|c|c|c|}
\hline \multicolumn{5}{|c|}{ A. Real Cost } \\
\hline $1996-97$ to $2015-16$ & 12787.2 & 2.15 & 25441.66 & 1.74 \\
\hline $1996-97$ to $2005-06$ & 12168.8 & 1.31 & 23730.81 & 0.79 \\
\hline $2006-07$ to $2015-16$ & 13405.5 & 3.32 & 27152.5 & 2.94 \\
\hline \multicolumn{5}{|c|}{ B. Nominal Cost } \\
\hline $1996-97$ to $2015-16$ & 18179.5 & 8.37 & 34714.52 & 7.94 \\
\hline $1996-97$ to $2005-06$ & 11046.2 & 5.04 & 21512.2 & 4.50 \\
\hline $2006-07$ to $2015-16$ & 25312.8 & 12.09 & 47916.84 & 11.68 \\
\hline $\begin{array}{l}\text { Source: Computed frc } \\
\text { Directorate of Econor }\end{array}$ & the Cost & ation & Various Y & $\begin{array}{l}\text { by } \\
\text { elfare }\end{array}$ \\
\hline
\end{tabular}




\section{Returns from Paddy Cultivation}

"Returns from crop cultivation are essential not only for the survival of the farmers but also for facilitating reinvestment in agriculture" (Pushpa et al., p. 388). From Table 2, it is observed that the return over paid out the cost at current prices has increased gradually over time. However, it is actually an illusory increase as inflation is included there. Returns at real prices reveal the accurate picture that paddy cultivation was more profitable 15 years ago than at present. The pathetic condition of the paddy farmers is disclosed if we look into the return over $\mathrm{C} 2$ cost, either at current prices or at real prices. From 2000-01 to 2015-16, the farmers incurred losses in paddy cultivation upto 14 times except for in 2007-08 and in 2009-10. Average net returns over the whole time period are negative (Rs.-1577 per hectare). Once more, during the second half of the period under study, the farmers have suffered higher losses than during the first half, as during the first half average net return per hectare was about Rs. (-) 1100 while it was Rs. (-) 2053 per hectare for the second half. So, it can be concluded that paddy cultivation in West Bengal is unprofitable.

\begin{tabular}{|l|l|l|l|l|}
\hline \multicolumn{1}{|l|}{ Table 2: Returns from Paddy Cultivation in West Bengal during 1996-97 to 2015-16 } \\
\hline Year & $\begin{array}{l}\text { Nominal Return } \\
\text { over paid out } \\
\text { cost } \\
\text { (Rs./Hectare) }\end{array}$ & $\begin{array}{l}\text { Real Return over } \\
\text { paid out cost (Rs./ } \\
\text { Hectare) }\end{array}$ & $\begin{array}{l}\text { Nominal Return } \\
\text { over C2 cost (Rs./ } \\
\text { Hectare) }\end{array}$ & $\begin{array}{l}\text { Real Return over } \\
\text { C2 cost (Rs./ } \\
\text { Hectare) }\end{array}$ \\
\hline $1996-97$ & 10788.20 & 14544.5 & 2159.68 & 2911.80 \\
\hline $1997-98$ & 10365.80 & 13327.5 & 1162.22 & 1494.24 \\
\hline $1998-99$ & 13327.10 & 14408.8 & 2890.92 & 3125.66 \\
\hline $1999-00$ & 10824.00 & 11895.7 & 363.66 & 399.67 \\
\hline $2000-01$ & 6672.73 & 7609.65 & -2776.64 & -3166.43 \\
\hline $2001-02$ & 7137.45 & 7844.13 & -3077.74 & -3382.50 \\
\hline $2002-03$ & 5736.83 & 6263.49 & -5151.97 & -5625.04 \\
\hline $2003-04$ & 8391.15 & 8704.84 & -3024.43 & -3137.38 \\
\hline $2004-05$ & 9823.63 & 9823.63 & -1898.35 & -1898.35 \\
\hline $2005-06$ & 10462.40 & 10187.00 & -1778.15 & -1731.40 \\
\hline $2006-07$ & 11468.40 & 10463.00 & -1560.40 & -1423.59 \\
\hline $2007-08$ & 14537.30 & 12255.50 & 512.78 & 432.29 \\
\hline $2008-09$ & 14782.90 & 11395.10 & -425.01 & -327.61 \\
\hline $2009-10$ & 21281.80 & 14061.20 & 3032.13 & 2003.39 \\
\hline $2010-11$ & 18872.50 & 11202.40 & -1263.33 & -749.88 \\
\hline $2011-12$ & 12925.00 & 7270.32 & -8628.89 & -4853.69 \\
\hline $2012-13$ & 19731.40 & 10031.40 & -7084.59 & -3601.72 \\
\hline $2013-14$ & 25489.40 & 11627.40 & -3607.66 & -1645.68 \\
\hline $2014-15$ & 21051.20 & 9284.84 & -12884.8 & -5682.88 \\
\hline $2015-16$ & 23302.70 & 10210.30 & -10688.5 & -4683.21 \\
\hline Source: Computed from the Cost of Cultivation Data of Various Years Published by the \\
\hline Directorate of Economics and Statistics, Ministry of Agriculture and Farmers Welfare \\
\hline
\end{tabular}

\section{MSP, Realised Price and Profitability: Are Paddy Famers Deprived?}

The government fixes MSP of major crops every year based on CACP's recommendation. Therefore, the trend of MSP and ratios of MSP to CoP would help us to understand whether MSP of the paddy has changed proportionately with the cost of production or not. The trend of MSP (Figure 2) shows that nominal MSP of paddy has increased over time and it has experienced rapid increase after 2006-07. Conversely, real MSP has experienced a relatively lower rate of increase, with ups and downs. From Table 3, it is 
observed that the ratio of MSP to C2 cost of production was either below 1 or close to 1 for the whole period, though the ratio of MSP to the A2 cost of production is well above 1.5. This indicates that paddy cultivation is an unprofitable activity if a farmer calculates C2 cost of production, but it is quite profitable if he calculates $A 2$ cost of production, assuming MSP as selling price. However, CACP considers A2+FL cost of production to set the MSP of crops, and it is observed that ratio of MSP to A2+FL cost is more than 1 but less than 1.5 for most of the years, which means paddy cultivation fetched less than 50 per cent return to the farmers.

\begin{tabular}{|c|c|c|c|}
\hline Year & $\begin{array}{l}\text { The ratio of MSP to C2 } \\
\text { Cost of Production }\end{array}$ & $\begin{array}{l}\text { The ratio of MSP to A2 } \\
\text { Cost of Production }\end{array}$ & $\begin{array}{l}\text { The ratio of MSP to } \mathrm{A} 2+\mathrm{FL} \\
\text { Cost of production }\end{array}$ \\
\hline 1996-97 & 1.00 & 2.04 & 1.68 \\
\hline 1997-98 & 0.97 & 1.90 & 1.54 \\
\hline 1998-99 & 0.90 & 1.79 & 1.43 \\
\hline 1999-00 & 1.00 & 2.04 & 1.54 \\
\hline 2000-01 & 1.03 & 2.03 & 1.5 \\
\hline $2001-02$ & 1.06 & 2.01 & 1.49 \\
\hline $2002-03$ & 0.97 & 1.79 & 1.35 \\
\hline 2003-04 & 1.01 & 1.93 & 1.43 \\
\hline 2004-05 & 0.97 & 1.90 & 1.42 \\
\hline 2005-06 & 0.98 & 1.92 & 1.44 \\
\hline 2006-07 & 0.93 & 1.82 & 1.36 \\
\hline 2007-08 & 1.11 & 2.26 & 1.67 \\
\hline 2008-09 & 1.23 & 2.28 & 1.74 \\
\hline 2009-10 & 1.16 & 2.21 & 1.65 \\
\hline $2010-11$ & 0.98 & 1.83 & 1.34 \\
\hline 2011-12 & 0.99 & 1.78 & 1.34 \\
\hline $2012-13$ & 1.01 & 1.94 & 1.38 \\
\hline $2013-14$ & 0.96 & 1.84 & 1.33 \\
\hline 2014-15 & 0.96 & 1.84 & 1.28 \\
\hline $2015-16$ & 0.99 & 1.88 & 1.33 \\
\hline
\end{tabular}




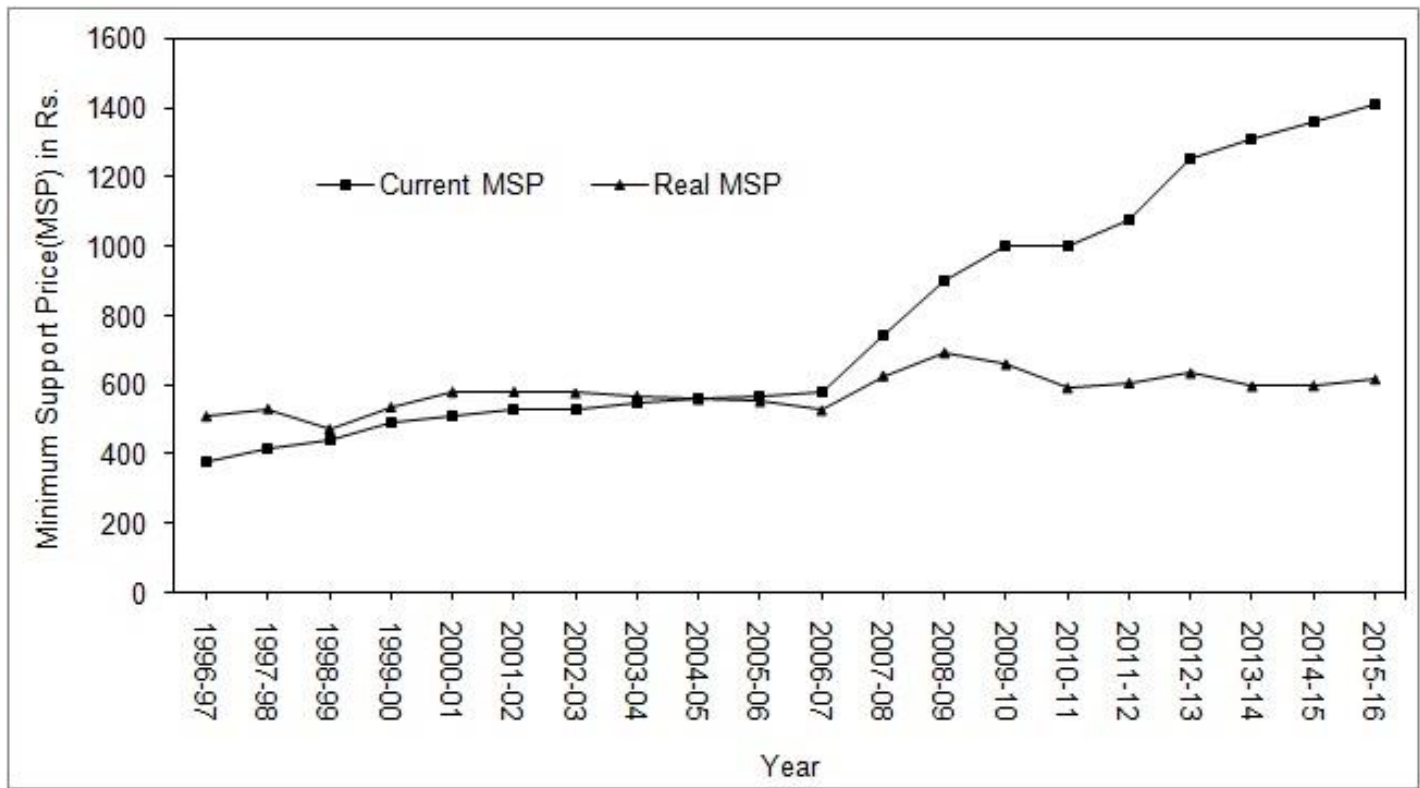

Figure 2: Growth Trend of MSP of Paddy in West Bengal

Source: Calculated using the Data from the Ministry of Agriculture \& Farmers Welfare, Government of India

However, the farmers are more concerned with the price they realise rather than the MSP (Dev \& Rao, 2010, p. 177). Therefore, the ratios of prices realised by the farmers to MSP of the paddy have been presented in Table 4 . The ratio of less than 1 , indicates realised price less than MSP. This table reveals that realised price was higher than the MSP only for five years out of 20 years during 1996-97 to 2015-16. A similar situation is observed in Orissa, Assam, Bihar and UP, whereas paddy farmers received more than MSP in states like Haryana, Himachal Pradesh,
Punjab, Madhya Pradesh, Chhattisgarh, Karnataka, Kerala, Andhra Pradesh and Tamil Nadu (Dev \& Rao, 2010, p. 177). One probable cause of such realised prices is that during the harvesting period, the local market price of paddy remains low; big traders further suppress the paddy price. Thus, resource-poor small and marginal farmers, having cash requirement, are compelled to sell their produce at prices less than MSP. In this way, the paddy growers of West Bengal are deprived by the government as well as by the local traders.

\begin{tabular}{|l|c|c|}
\hline \multicolumn{3}{|l|}{ Table 4: Changes in Realised Prices in Relation to MSP of Paddy in West Bengal } \\
\hline Year & Price Realised at Current Prices & \multicolumn{2}{|c|}{$\begin{array}{l}\text { The Ratio of Realised Price to } \\
\text { MSP }\end{array}$} \\
\hline $1996-97$ & 438.77 & 1.15 \\
\hline $1997-98$ & 461.93 & 1.11 \\
\hline $1998-99$ & 572.74 & 1.30 \\
\hline $1999-00$ & 500.77 & 1.02 \\
\hline $2000-01$ & 409.05 & 0.80 \\
\hline $2001-02$ & 415.27 & 0.78 \\
\hline $2002-03$ & 411.19 & 0.78 \\
\hline $2003-04$ & 465.86 & 0.85 \\
\hline $2004-05$ & 525.74 & 0.94 \\
\hline $2005-06$ & 533.63 & 0.94 \\
\hline $2006-07$ & 583.29 & 1.01 \\
\hline $2007-08$ & 682.35 & 0.92 \\
\hline $2008-09$ & 720.38 & 0.80 \\
\hline
\end{tabular}




\begin{tabular}{|c|c|c|}
\hline 2009-10 & 943.94 & 0.94 \\
\hline 2010-11 & 988.70 & 0.99 \\
\hline 2011-12 & 870.88 & 0.81 \\
\hline $2012-13$ & 1060.02 & 0.85 \\
\hline 2013-14 & 1275.68 & 0.97 \\
\hline 2014-15 & 1130.26 & 0.83 \\
\hline $2015-16$ & 1190.27 & 0.84 \\
\hline
\end{tabular}

\section{Farmers' Perception}

From the above discussion, it is very clear that paddy cultivation is now a loss-making economic activity. Thus, the question arise, why are farmers sticking to paddy cultivation ? In any way, is paddy cultivation a profitable venture for the farmers? In response to these questions, the farmers responded differently to the same question.

Interestingly, only 7.8 per cent farmer households opined that paddy cultivation incurred loss. About 37.2 per cent farmer households opined there is either no profit or no loss in paddy cultivation. About 46.3 per cent farmer households perceived that paddy cultivation fetched very low to low-profit margin to them. The causes behind such perceptions are not same for all types of farmer households. Landless lessee and sharecropper households have blamed that landowners leased out relatively bad landholdings to them. Besides, they have to pay share of output to the landowner. All these factors lessen their profit. However, according to other categories of farmer households, full dependence on hired labour and hired farm implements are most crucial causes for becoming paddy cultivation an unprofitable venture.

Only a few farmer households (8.5 per cent) believed that paddy cultivation is moderate to highly profitable. About 21.1 per cent of the big farmer households and about 20 per cent of the landless lessee farmer households too perceive so, though they do not provide reasonable arguments in favour of high profitability of paddy cultivation. They mentioned that productivity has increased in comparison to the
20-25 years ago, but as consumption expenditure per households has increased rapidly over time, it apparently seems that profitability of paddy cultivation is going down.

Many researchers have proved that profitability of a crop may vary among the different categories of farmers depending on labour use, input use, technology use (Gaurav \& Mishra, 2011; Chand, Lakshmi Prassana, \& Singh, 2011; Ranganathan, 2015). Besides, from the farmers' cost analysis (Table 5), it has been observed that profitability varies based on seed varieties and crop seasons. However, the important question is: why does the perception of the farmers differ from experts' opinion to such a large extent?

The answer to this question is perhaps that except for a few farmers, the others miscalculate the cost of cultivation. The leading cause of such exaggerated profit is that they only include the input costs of seed, fertilisers and pesticides, irrigation, hired human and machine labour (Table 5). Besides, farmers do not keep detailed records of all costs incurred, and they calculate the cost arbitrarily. They do not include cost items like family labour, own farm yard manure or own machine use, the maintenance cost of the farm implements. Most of the farmers do not know what depreciation cost is or what rent on fixed capital is. Interestingly, the majority of them do not even include the cost of bags used for packing the grains. Exclusion of these cost items lessens the apparent cost of cultivation.

Another cause for exaggerated profit is that farmers include income from paddy business as return from agriculture. According to the ADA officials, if a farmer stores his produce at home for a few months and sells it after the rise of 
market prices, then it should be considered as income or profit from business. This profit should not be included as a return from cultivation.

\section{Conclusion}

It can, therefore, be concluded that farmers make many mistakes in their cost calculation that results in reporting of exaggerated profits from paddy cultivation. This type of faulty calculation also helps them to continue paddy cultivation at the time when experts opine it as unprofitable. However, most of the farmers perceive that they are continuing paddy cultivation as it helps to meet the family needs either partly or wholly, and there is a lack of opportunity for engaging in other gainful economic activity due to various causes.

The cash crops like potato and onion are gaining importance in the study area like in West Bengal, but these crops have also failed to fetch considerable profits regularly in recent times. Moreover, shifting from food crops to cash crops may create food insecurity in future. One-time incentives like loan waivers is also not a solution, as most of the marginal and small farmers either do not get institutional loans or prefer to repay the loans before/in time any how.

There are many loopholes in paddy procurement scheme of the Government. Most of the marginal and small farmers have alleged corruption in the distribution of coupons required for selling paddy at procurement centres. Further, there is presence of middlemen in the procurement system. The government has also failed to procure paddy immediately after harvesting. Besides, farmers blamed that

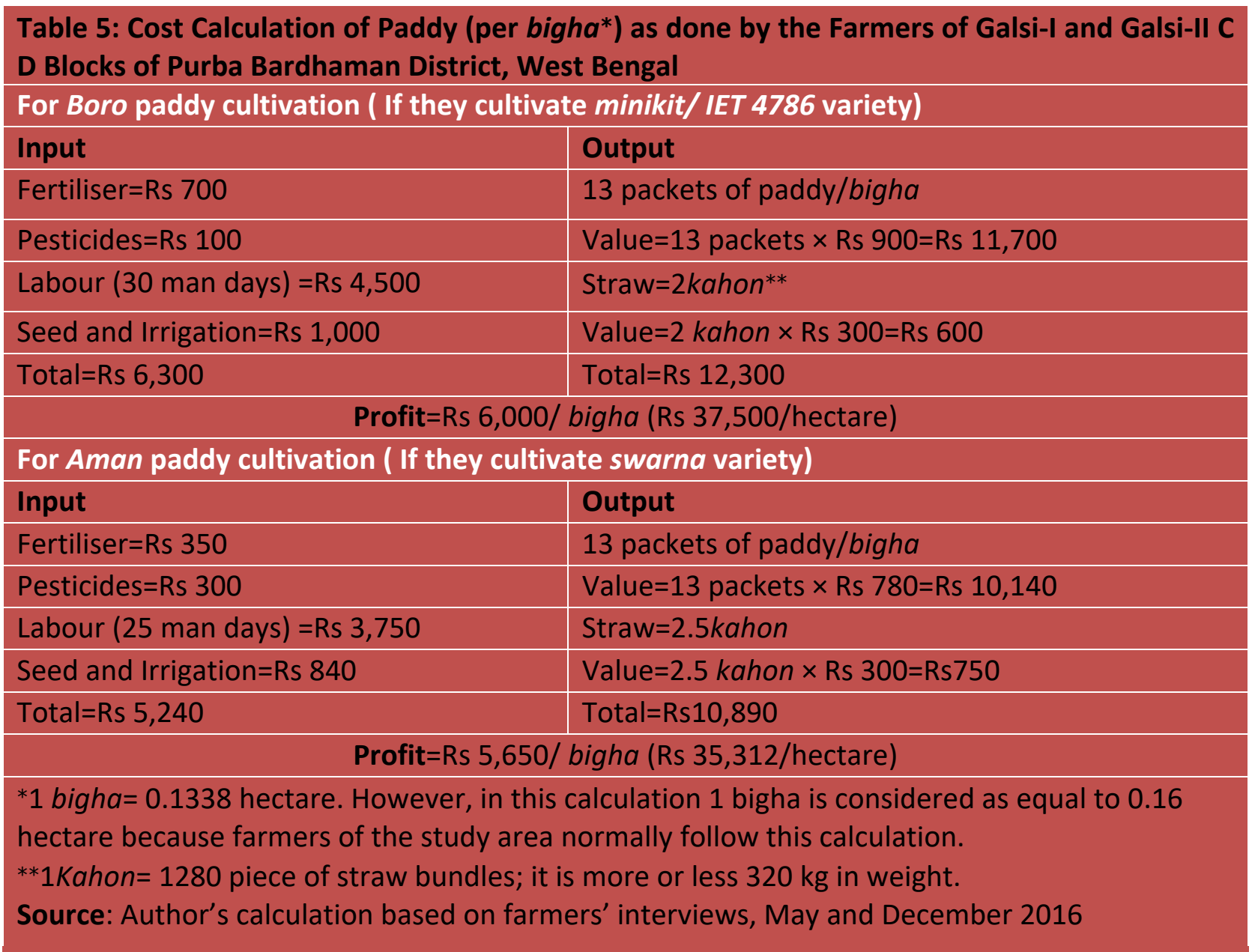

procurement agencies are levying an unlawful forced to bear high transportation cost to bring cut on the amount of paddy. Farmers are also their produce to procurement centres. 
However, the state, as well as central governments, have recently announced that they would provide a sum of money every year as direct incentives to farmers ("Krishak Bandhu", 2018; "Budget 2019", 2019). This is also good for the farmers, but if the government would take steps to provide the right price of produce (at least $50 \%$ profit over C2 cost) then profit would be far higher than the number of incentives. Finally, the government should train and empower farmers so that they can adequately calculate the cost of cultivation because it is essential to assess the cost and returns from an economic activity before engaging in it.

\section{References}

Biru, B. K., \& Barpujari, I. (n.d.). Jan Sunwai on the present agrarian crisis. Gene Campaign, 1-42. Retrieved on February 8, 2019, from https://genecampaign.org/wpcontent/uploads/2014/07/THE_AGRARIAN_ CRISIS_IN_INDIA.pdf

Budget 2019: Modi govt's new scheme offers Rs 6000 directly into farmers' bank accounts. (2019, February 1). Business Today. Retrieved on February 8, 2019 from https://www.businesstoday.in/budget2019/news

Chand, R., Lakshmi Prassana, P. A., \& Singh, A. (2011). Farm size and productivity: Understanding the strengths of smallholders and improving their livelihoods. Economic and Political Weekly, XLVI (26\&27), 5-11.

Chand, R., Saxena, R., \& Rana, S. (2015). Estimates and analysis of farm income in India, 1983-84 to 2011-12. Economic and Political Weekly, 50 (22), 139-145.

Dev, S. M., \& Rao, N. C. (2010). Agricultural price policy, farm profitability and food security. Economic and Political Weekly. XLV (26-27), 174-182.

Directorate of Economics and Statistics. (n.d.). Cost of Cultivation/Production and Related Data. Retrieved from https://eands.dacnet.nic.in/Cost_of_Cultivati on.htm
Gaurav, S., \& Mishra, S. (2011). Size class and return to cultivation: A cold case reopened. Indira Gandhi Institute of Development Research, Mumbai. 1-24. Retrieved on August 27, 2018, from http://www.igidr.ac.in/pdf/publication/WP2011-027.pdf

Krishak Bandhu: Mamata announces sops for farmers. (2018, December 31). The Hindu. Retrieved on February 8, 2019, from https://www.thehindubusinessline.com

Langa, M., \& Sriram, J. (2017, June 10). Farmers' protest: Fault lines in the fields. The Hindu. Retrieved on December 4, 2018, from https://www.thehindu.com/news/national/o ther-states/fault-lines-in-thefields/article18951520.ece

Mohanty, B. K. (2018, December 3). Why our farmers are so angry. The Telegraph, p. 1.

Narayanamoorthy, A. (2013). Profitability in crops cultivation in India: Some evidence from cost of cultivation survey data. Indian Journal of Agricultural Economics, 68 (1), 104-121.

Narayanamoorthy, A., Alli, P., \& Suresh, R. (2014). How profitable is cultivation of rainfed crops? Some insights from cost of cultivation studies. Agricultural Economics Research Review, 27 (2), 231-241.

Nath, S.K. (2008). Manual on Cost of Cultivation Surveys, Ministry of Statistics and Programme Implementation, Government of India. Retrieved fromhttp://mospi.nic.in/sites/default/files/p ublication_reports/manual_cost_cultivation_ surveys_23july08_0.pdf

Posani, B. (2009). Crisis in the countryside: Farmer suicides and The Political Economy of Agrarian Distress in India (No. 09-95). London. Retrieved on February 25, 2018, from http://www.Ise.ac.uk/internationalDevelop ment/pdf/WP/WP95.pdf

Pushpa., Srivastava, S. K., \& Agarwal, P. K. (2017). Comparative study on cost of cultivation and economic returns from major 
crops in eastern region of Uttar Pradesh. International Journal of Agriculture, Environment and Biotechnology, 10 (3), 387399. Retrieved on September 1, 2018, from http://ndpublisher.in/admin/issues/IJAEBv10 n3p.pdf

Raghavan, M. (2008). Changing pattern of input use and cost of cultivation. Economic and Political Weekly, 43 (26-27), 123-129.

Ranganathan, T.(2015). Farmers' income in India: Evidence from Secondary Data. Agricultural Situation in India, 72 (3), 30-70, Institute of Economic Growth, New Delhi.

Rao, C. H. H. (2004). Preface to millennium study. In G.S Bhalla, Globalisation and Indian Agriculture, New Delhi, India: Academic Foundation.

Ray, S. (2007). Economic policy and agriculture. In Shovan Ray (Ed.), Handbook of agriculture in India, New Delhi, India: Oxford University Press, 34-56.

Shroff, S.(2019, April 8). Rethinking India's battles against chronic agrarian distress. The Hindu Centre for Politics and Public Policy. Retrieved on April 20, 2019, from https://www.thehinducentre.com/thearena/current-issues/article26754462.ece

Srinivasan, P.V. (2007). Agriculture and food security. In Shovan Ray (Ed.), Handbook of Agriculture in India, New Delhi, India: Oxford University Press, 130-167.
Srivastava, S. K., Chand, R., \& Singh, J. (2017). Changing crop production cost in India: Input prices, substitution and technological effects. Agricultural Economics Research Review, 30, 171-182.

Swaminathan, M. S. (2016). National policy for farmers: Ten years later. Review of Agrarian Studies, 6(1), 133-144. Retrieved on August 27, 2018, from http://www.ras.org.in/national_policy_for_f armers_ten_years_later

Tripathi, A. K. (2013). Agricultural price policy, output and farm profitability - examining linkages during postreform period in India. Asian Journal of Agriculture and Development, 10 (1), 91-111.

Why the farmers have stormed Delhi, what they want. (2018, Nov 30). The Economic Times. Retrieved on December 3, 2018, from https://economictimes.indiatimes.com/news /et-explains/why-the-farmers-have-stormeddelhi-what-theywant/articleshow/66881527.cms

\section{Acknowledgements}

The author is thankful to Professor Gopa Samanta, Department of Geography, The University of Burdwan for her valuable suggestions, and also expresses his sincere gratitude to the anonymous reviewers for their comments on improving this article. 